\title{
The potential of small exclosures in assisting regeneration of coffee shade trees in South-Western Ethiopian coffee forests
}

\author{
Kitessa Hundera $^{1,2 *}$, Olivier Honnay ${ }^{3}$, Raf Aerts ${ }^{2}$ and Bart Muys ${ }^{1}$ \\ ${ }^{1}$ Division Forest, Nature and Landscape, University of Leuven, Celestijnenlaan 200E-2411, BE-3001, Leuven, Belgium, ${ }^{2}$ Department of Biology, \\ Jimma University, P.O. Box 8 378, Jimma, Ethiopia and ${ }^{3}$ Plant Conservation and Population Biology, University of Leuven, Kasteelpark Arenberg \\ 31-2435, BE-3001, Leuven, Belgium
}

\begin{abstract}
Ethiopian Afromontane moist forests where coffee grows as understorey shrub are traditionally managed by the local communities for coffee production through thinning of the shade tree canopy and slashing of competing undergrowth. This management practice has a negative impact on the coffee shrubs, because the removal of shade tree saplings and seedlings reduces the succession potential of the shade tree canopy, which threatens the very existence of the shade coffee production system. We assessed the functionality of small exclosures to initiate coffee shade tree canopy restoration through natural regeneration. Our results show that small exclosures have a strong restoration potential for the coffee shade trees preferred by farmers (Albizia schimperiana, A. gummifera and Millettia ferruginea), as evidenced from their seedling abundance, survival and growth. The regeneration of late-successional tree species of the moist Afromontane forest was not successful in the small exclosures, most probably due to the low abundance or absence of adult trees as seed sources for regeneration. Therefore, temporary establishment of small exclosures in degraded coffee forest fragments where shade trees are getting old or dying is recommended for sustainable shade coffee production.
\end{abstract}

Key words: Coffea arabica, coffee management, dispersal limitation, seedling survival

\section{Résumé}

Les forêts humides afromontagnardes d'Éthiopie, où le café pousse en arbustes des sous-bois, sont traditionnellement gérées par les communautés locales qui produisent du café

*Correspondence: E-mail: kitessah2@yahoo.com en éclaircissant les arbres d'ombrage de la canopée et en coupant les sous-bois qui feraient concurrence aux plants de café. Cette pratique de gestion a un impact négatif sur ces derniers parce que l'enlèvement des jeunes plants et pousses des arbres d'ombrage réduit le potentiel de succession des arbres d'ombrage de la canopée, ce qui menace l'existence même du système de production de café d'ombre. Nous avons évalué la fonctionnalité de petits enclos-exclos pour initier, par une régénération naturelle, la restauration d'une canopée d'ombrage pour le café. Nos résultats montrent que de petits enclos-exclos ont un fort potentiel de restauration pour les arbustes de café d'ombre préférés des exploitants (Albizia schimperiana, A. gummifera et Millettia ferruginea), preuve en est l'abondance des jeunes plants, leur survie et leur croissance. La régénération des espèces d'arbres qui viennent en fin de succession dans la forêt humide afromontagnarde n'a pas réussi dans les petits enclos-exclos, très probablement à cause de la faible abondance, voire de l'absence d'arbres adultes, sources de semences pour la régénération. C'est pourquoi, afin d'atteindre une production durable de café d'ombre, nous recommandons d'établir temporairement de petits enclos-exclos dans des fragments dégradés de forêts de caféiers où les arbres d'ombrage deviennent vieux ou meurent.

\section{Introduction}

Arabica coffee (Coffea arabica L.) is a native understorey shrub of the moist Afromontane forests of south-west Ethiopia (Anthony et al., 2002). It is a shade-tolerant plant, but excessive cover by a dense upper canopy decreases growth and coffee productivity (Geromel et al., 
2008; Franck \& Vaast, 2009). The dense canopy reduces the light availability below levels of optimal coffee shrub growth and fruiting, and the trees and ground vegetation are likely to compete for water and mineral resources (Beer et al., 1998). Therefore, these forests (also known as coffee forests) are traditionally managed by local communities to optimize shade and maximize coffee production (Senbeta \& Denich, 2006) because coffee is their major source of income (Gole, 2003; Schmitt et al., 2009). Coffee management essentially involves thinning of the forest canopy (Schmitt et al., 2009; Aerts et al., 2011). Coffee management further includes periodic slashing of herbs, lianas and shrubs that compete with coffee shrubs for light and nutrient resources, affecting coffee berry production.

The continuous practice of coffee forest manipulation to increase coffee productivity has a negative effect, not only on the forest species composition and forest structure, but in the long term also on coffee productivity itself (Senbeta \& Denich, 2006) by exposing the coffee shrubs to adverse environmental conditions. In coffee forests in areas of high human population density, the intensity of tree removal and canopy thinning is very high (Hundera et al., 2013). As a consequence, late-successional species with valuable timber are preferentially thinned, while early-successional legume species with transparent canopy are conserved in the canopy (Hundera et al., 2013). Furthermore, also the slashing of the lower vegetation is very intense. This practice involves slashing the ground cover over the whole area of the coffee forest, every year at the end of the rainy season (October and November), resulting in the removal of overstorey shade tree seedlings and saplings (Hundera et al., 2013). It can be expected that this practice may arrest tree regeneration and reduces the succession potential of the shade trees. Indeed, in the absence of natural regeneration, the existing shade trees will eventually mature, reach postreproductive stage and die (Senbeta \& Denich, 2006), exposing the coffee plants to altered environmental conditions (Bote \& Struik, 2011). This is already evidenced by lack of trees in smaller diameter classes in many of the coffee forest fragments (Hundera et al., 2013).

The present management may have caused arrested succession of the upper canopy trees due to seed limitation of certain tree species (low density of adults) and recruitment limitation of others (through slashing). Persistence of this situation may threaten the very existence of the shade coffee production system (Senbeta \& Denich, 2006). Shade trees provide a range of benefits to coffee plants including reduction of air and soil temperature extremes and reduction in the quantity and quality of transmitted light and hence avoidance of overbearing (Beer et al., 1998; Bote \& Struik, 2011). Shading delays the maturation of coffee berries and consequently results in better bean filling, larger bean size and better coffee quality (Muschler, 2001; Morais et al., 2006).

Exclosures as an ecosystem rehabilitation technique have demonstrated a positive impact on natural vegetation regrowth on formerly degraded areas and open-access lands (e.g. Opperman \& Merenlender, 2000; Mengistu, 2001; Dereje et al., 2002; Cheng et al., 2011). These are areas closed off from the interference of human and domestic animals to encourage natural regeneration of plants and reducing land degradation of formerly degraded lands (Aerts, Nyssen \& Haile, 2009; Mekuria \& Aynekulu, 2011).

Even though establishment of exclosures has been promoted as a promising rehabilitation method of degraded areas in northern Ethiopia (e.g. Mengistu et al., 2005; Aerts et al., 2008; Wassie et al., 2009; Mekuria \& Veldkamp, 2012), limited research has been conducted on the impact of exclosures in restoring shade trees in moist Afromontane coffee forests which are degraded in composition and structure as a result of coffee management practices. Therefore, the objective of this study was to evaluate the effectiveness of exclosures for initiating successful regeneration of the coffee forest canopy in coffee forests. Exclosures for forest regeneration are generally in the order of hectares (Aerts et al., 2007; Mekuria \& Veldkamp, 2012), but here the intention was to foster regeneration of canopy trees by reducing the common coffee management by the farmer to a minimum. We adopted the idea of using small exclosures with an area of $<100 \mathrm{~m}^{2}$. In this study, we specifically show the effect of small exclosures on species richness, community composition, abundance, survival and growth of the regenerating tree species.

\section{Materials and methods}

\section{Study area, sampling design and data collection}

Eighteen coffee forest fragments varying in size from 1 to 100 ha were selected at a site known as Garuke in the Manna district of the Jimma Zone, south-west Ethiopia (Fig. 1). The area is situated in an undulating landscape consisting of a mosaic of crop land, pasture, riverine 


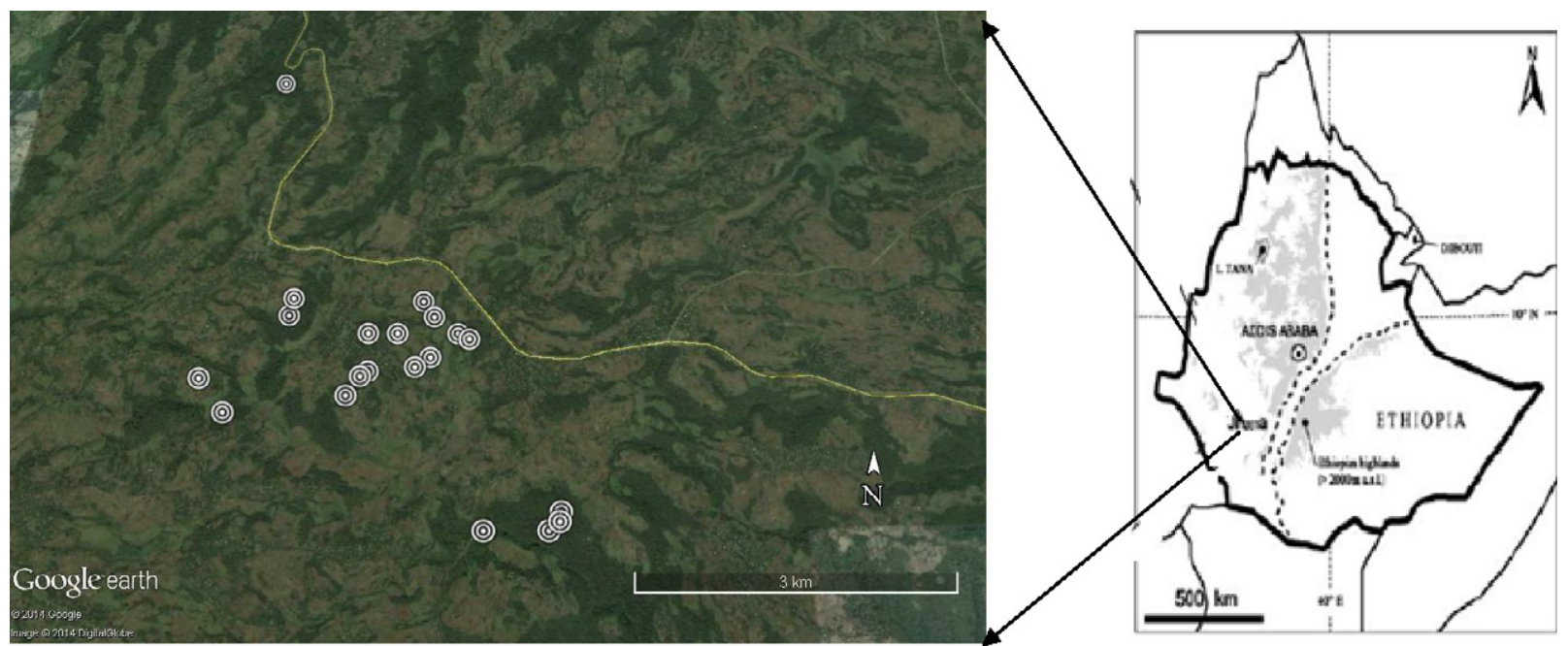

Fig 1 Location of the fragments in Garuke where exclosures established; Jimma zone, south-west Ethiopia, Satellite imagery@2013 DigitalGlobe, Google Earth

wetland, small human settlements and isolated farmsteads (Aerts et al., 2011). The area has an average yearly temperature of $20.3^{\circ} \mathrm{C}$ and a precipitation of $1777 \mathrm{~mm}$ (Ethiopian Meteorological Agency, Jimma station). The dominant soil types of the area are Nitisols (Asres, 1996).

Prior to coffee cultivation and forest management, the natural forest community probably represented the Afromontane moist forest. The presence of few scattered or isolated mature trees of late-successional species, such as Podocarpus falcatus (Thunb.) R.Br. ex Mirb., Olea welwitschii (Knobl.) Gilg \& Schellenb. and Prunus africana (Hook.f.) Kalkman, in the farmlands and in the remaining coffee forest fragments reminds us of the original forest ecosystem. The specific site of the plot in each fragment where small exclosures were established was based on the willingness of the farmers to put these small exclosures in their coffee farms. Twenty-four exclosures of size $10 \times 10 \mathrm{~m}$ were established in March 2010 using wooden pole and barbed wire. All exclosures were kept free from slashing and all human disturbances. For comparison, a control plot of the same size, where the slashing and other human disturbances continued to take place, was established near every exclosure. There was a little variability in edaphic and microclimatic conditions between exclosures and control plots as they were established at a short distance of $5 \mathrm{~m}$ from each other. The canopy closure and leaf area index (LAI) of exclosures and control plots were measured using a spherical densiometer and camera with hemispherical lens, respectively. All mature canopy trees (which had started flowering and fruiting) in the exclosures and the control plots as well as those whose crown covers the exclosures were recorded.

Tree species regenerating (seedling emerging from seeds or as root suckers) in exclosures and control plots were identified, and the number of individuals of each species (abundance) and survival were recorded at 3 months intervals for 2 years. In addition, in the exclosures, all tree seedlings encountered in the 3 months after establishment of the exclosures (517 individual seedlings) were tagged, and their survival and growth change were monitored for the same period. Data collection started 3 months after the exclosures were established.

\section{Data analysis}

Seedling species richness, abundance (total seedlings of all species) and Shannon's diversity index were calculated for both the exclosures and the controls, at every 3 month interval. The seedling community composition was analysed using non-metric multidimensional scaling (NMDS) ordination to evaluate change in seedling community composition over time. Then, we assessed the effect of exclosures as compared to the control groups over time on seedling abundance, species richness, Shannon's diversity index and community composition (the scores of the plots on the two NMDS axis) using one-way repeated-measures ANOVA. Per cent canopy cover and leaf area index (LAI) were added as covariates in the analysis to control for the effect of canopy density on the regeneration. 
The Greenhouse-Geisser adjustment to the degrees of freedom for the F-test was used to interpret within-subject trends (Quinn \& Keough, 2002) to meet the assumptions of sphericity of the data (Lawes \& Chapman, 2006). Correlation between seedling abundance in the exclosures with abundance of adult trees in the fragments was explored using a Pearson correlation coefficient.

The seedling survival in the exclosures was explored using the Kaplan-Meier survival analysis (Altman \& Bland, 1998). Also the survival of the three most commonly regenerating coffee shade tree species (Millettia ferruginea Hochst., Albizia gummifera C.A.Sm and Croton macrostachyus Hochst. ex Delile) in the exclosures was compared using the same procedure. A time-to-event approach was used to analyse the seedling survival over time (Altman \& Bland, 1998) by considering death of seedlings as the critical event (time interval from the date of tagging until death).

Height growth was assessed by calculating the growth rate (GR), which expresses growth in terms of a rate of increase in height per unit of initial height (Wassie et al., 2009). GR $=\left(H_{\mathrm{n}}-H_{0}\right) /\left(t_{\mathrm{n}}-t_{0}\right)$, where $H_{\mathrm{n}}$ is the height measured at time $t_{\mathrm{n}} ; H_{0}$ the initial height measurement; $\left(t_{\mathrm{n}}-t_{0}\right)$ is the unit time differences between specified time. Based on the result, the difference in height growth was compared with ANOVA using the log-transformed change in growth per year. Then, the height growth for the five most abundant species was compared among themselves. All the analyses were conducted using SPSS 16.0 (IBM, Chicago, NY, U.S.A) except the NMDS ordination which was conducted by PC-ORD 5.31 (MjM Software, Gleneden Beach, OR, U.S.A).

\section{Results}

Effect of small exclosures on seedling abundance

In the exclosures, seedling abundance increased in the first 6 months after establishment and then started to decline steadily, while in the control plots, it showed increases and decreases following the periodic cycle of slashing (Fig. 2a). There was a significant difference in seedling abundance between the exclosures and the control plots over time $\left(\mathrm{F}_{1.93,48}=8.39, \mathrm{P}=0.001\right)$. Species richness was also significantly different between the exclosures and control plots over time $\left(\mathrm{F}_{7,48}=3.31, P=0.007\right)$ (Fig. 2b), with a mean species richness per plot of $3.7 \pm 0.28$ in exclosures and $1.7 \pm 0.24$ in controls. In total, 19 species of coffee shade tree seedlings were recorded regenerating in the exclosures, while only eight species in the control plots throughout the study period (Table 1).

Effect of exclosures on community composition and diversity

In the exclosures, abundance of the seedlings varies greatly among species. Albizia spp. (A. gummifera and A. schimperiana) comprise $56 \%$ of the total amount of seedlings tagged, followed by Prunus africana (9\%), Syzygium guineense (8\%), Millettia ferruginea (7\%) and Croton macrostachyus (5\%). Albizia gummifera and A. schimperiana were also the most commonly regenerating species, occurring in more than $80 \%$ of the exclosures, followed by Bersama abyssinica (46\%), Maesa lanceolata, Millettia ferruginea and Prunus africana each in $41 \%$ of the exclosures. Only three of the regenerating species were late-successional species of the moist Afromontane forest (Table 1). One late-successional and seven early-successional tree species occurring in or near the exclosures as mature trees were not regenerating in both the exclosures and the control plots (Table 1). All recorded seedlings in both the exclosures and control plots were found at an average distance of $14 \mathrm{~m}$ from a mature tree of the same species, except Prunus africana and Olea welwitschii that were found at an average distance of about $200 \mathrm{~m}$ and $500 \mathrm{~m}$, respectively.

The exclosures and the control plots largely differed in Shannon's diversity index $\left(\mathrm{F}_{2.02 .48}=3.14 \mathrm{P}=0.04\right)$. In the exclosures, there was a slight increase in the diversity index over time, while in the control plots, it followed the pattern of the slashing cycles (Fig. 2c). Nevertheless, the difference in community composition was never significant between the exclosures and the control plots over time (NMDS1, $F_{4 \cdot 6,48}=0.037, P=0.99$; NMDS2, $\left.\mathrm{F}_{3.6,48}=0.55, P=0.9\right)$.

Effect of exclosures on seedling survival and growth

Seedling survival decreased (mortality increased) significantly in exclosures with little mortality after 12 months (ANOVA $\mathrm{F}_{7,24}=3.1 P=0.02$ ) (Fig. 3). Only 39\% (n= $201)$ of the total seedling tagged $(n=517)$ for follow-up survived after 2 years.

Seedling survival varied greatly between the commonly regenerating preferred coffee shade trees, that is Albizia spp. (A. gummifera and A. schimperiana), Croton macrostachyus and Millettia ferruginea (estimated mean $\pm \mathrm{SE}=14.5 \pm 0.38$, 

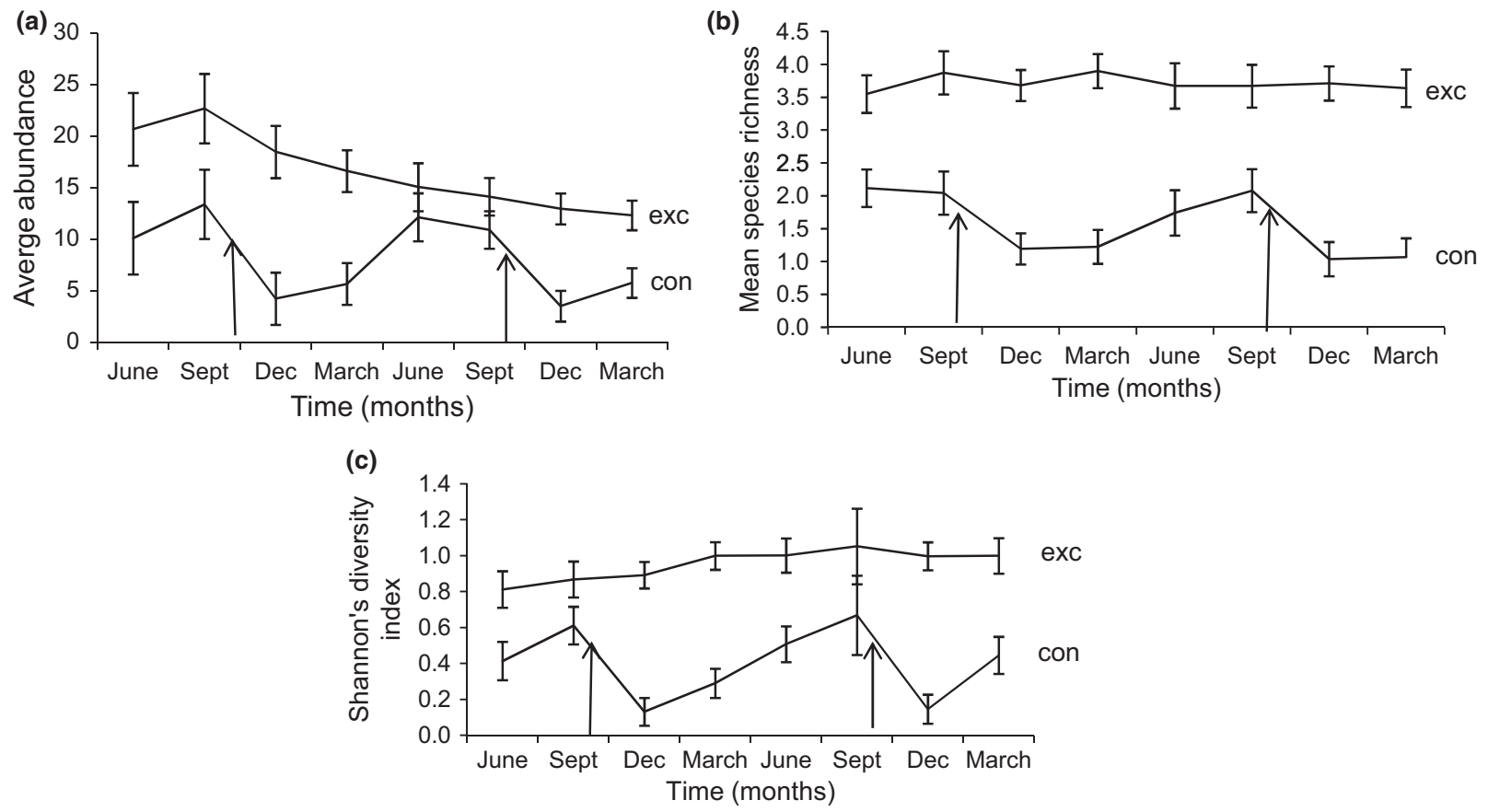

Fig 2 Evolution of (a) seedling abundance, (b) species richness and (c) Shannon's diversity index in exclosures (exc) and control plots (con) in Garuke coffee forest fragments, south-west Ethiopia, between June 2010 and March 2012; arrows indicate time of slashing; error bars denote standard error

$10.4 \pm 1.4$ and $19.5+0.94$, respectively; Fig 4). Growth rate was significantly different between the five commonly occurring shade tree species compared $\left(\mathrm{F}_{5,148}=11.73\right.$ $P<0.001)$. Croton macrostachyus and Macaranga capensis had the highest growth rate per year, while Albizia and Prunus africana had the lowest (Fig 5).

\section{Discussion}

Our study revealed the potential of small exclosures to initiate regeneration of coffee shade trees in the intensively managed coffee forests. As is evident from the diversity and density of observed coffee shade tree seedlings, seed availability and germination capacity is not a limiting factor for the restoration of coffee shade canopy tree species preferred by local farmers. Almost all preferred shade tree species (Albizia and Millettia) (Aerts et al., 2011; Muleta et al., 2011; Hundera et al., 2013a) were found effectively regenerating, growing and surviving in the exclosures.

The increase in seedling density in the first few months following the establishment of the exclosures was facilitated by the preceding slashing by farmers, ensuring removal of competing herbs and shrubs for resource and space and encouraging the successful germination and establishment of the shade tree seedlings. The subsequent decline in seedling abundance after 6 months might be as a result of competition for space and resources by proliferating herbs and shrubs in the exclosures (Harmer, Boswell \& Robertson, 2005). The impact of ground flora on seedlings could be either by competing for soil moisture and nutrients or by providing suitable habitats for animals that can damage seedlings or both (Harmer, Boswell \& Robertson, 2005). The magnitude of this effect on growth and survival of seedlings varies with species and site. The impact of clearing competing herbs and shrubs in facilitating germination and seedling survival in disturbed forests is well documented (e.g. Robinson \& Handel, 2000). The decline in seedling mortality after 1 year can be explained by the fact that remaining seedlings established themselves by outcompeting shrubs and herbs.

The dominance of the seedlings of Albizia gummifera and A. schimperiana in abundance and frequency in the exclosures might be associated with reproductive adult abundance (Comita et al., 2007) as these two species predominate in the semi-forest coffee fragments (Hundera 
Table 1 Frequency of occurrence of coffee shade tree species regenerating/not regenerating in exclosures and control plots at Garuke coffee forest fragments and their successional stage and dispersal mode, Jimma zone, south-west Ethiopia

\begin{tabular}{|c|c|c|c|c|c|}
\hline Species & Family & Exclosure (\%) & Control & Successional stage* & Dispersal mode* \\
\hline Albizia schimperiana Oliv & Fabaceae & 78 & 65 & Early & Wind \\
\hline Albizia gummifera C.A.Sm & Fabaceae & 78 & 78 & Early & Wind \\
\hline Albizia grandibracteata Taub & Fabaceae & 33.3 & 0 & Early & Wind \\
\hline Allophylus abyssinicus Radlk & Sapindaceae & 33.3 & 21 & Early & Animal \\
\hline Bersama abyssinica Fresen & Melianthaceae & 46 & 13 & Early & Wind \\
\hline Brucea antidysenterica J.F.Mill & Simaroubaceae & 29 & 33 & Early & Animal \\
\hline Celtis africana Burm.f & Ulmaceae & 21 & 0 & Early & Animal \\
\hline Cordia africana Lam & Boraginaceae & 5 & 0 & Early & Animal \\
\hline Croton macrostachyus Hochst. ex Delile & Euphorbiaceae & 42 & 33 & Early & Wind \\
\hline Ehretia cymosa Thonn & Boraginaceae & 13 & 5 & Early & Animal \\
\hline Ekebergia capensis Sparrm & Meliaceae & 5 & 0 & Early & Animal \\
\hline Macaranga capensis Sim & Euphorbiaceae & 8 & 5 & Early & Wind \\
\hline Maesa lanceolata Forssk & Myrtaceae & 42 & 33 & Early & Birds \\
\hline Millettia ferruginea Hochst. & Fabaceae & 42 & 33 & Early & Wind \\
\hline Olea welwitschii Gilg \& G. Schellenb & Oleaceae & 5 & 0 & Late & Animal \\
\hline Prunus africana (Hook.f.) Kalkman & Rosaceae & 42 & 0 & Late & Animal \\
\hline Sapium ellipticum Pax & Euphorbiaceae & 5 & 0 & Early & Wind \\
\hline Syzygium guineense DC & Myrtaceae & 33 & 0 & Early & Animal \\
\hline Teclea nobilis Delile & Rutaceae & 5 & 0 & Late & Animal \\
\hline Acacia abyssinica Hochst. ex Benth & Fabaceae & 0 & 0 & Early & Wind \\
\hline Erythrina abyssinica Lam & Fabaceae & 0 & 0 & Early & Wind \\
\hline Ficus thonningii Blume & Moraceae & 0 & 0 & Early & Animal \\
\hline Ficus sycomorus L. & Moraceae & 0 & 0 & Early & Animal \\
\hline Polycias fulva Hutch. \& Dalziel & Araliaceae & 0 & 0 & Early & Wind \\
\hline Pouteria adolfi-friederici (Engl.) A. Meeuse & Sapotaceae & 0 & 0 & Late & Animal \\
\hline Premna schimperi Engl & Lamiaceae & 0 & 0 & Early & Animal \\
\hline Schefflera abyssinica Harms & Araliaceae & 0 & 0 & Early & Animal \\
\hline
\end{tabular}

*http://www.worldagroforestry.org/treedb2/, http://www.prota.org/, http://www.worldagroforestrycentre.org.

et al., 2013). The dominance of seedlings of the earlysuccessional species and inability of some late-successional plants to regenerate can be due to seed limitation as a result of low density of adults or limited seed dispersal (Clark, Macklin \& Wood, 1998) in the intensively managed fragments, as the density of the shade demanding late-successional species is very low in the managed fragments (Aerts et al., 2011; Hundera et al., 2013). The relative abundance of seedlings of Syzygium guineense (230 individuals per ha) in the fragments as compared to that of other climax tree species such as $O$. welwitschii (four individuals per ha) is a consequence of its higher adult tree abundance (48 individuals per ha versus two individuals per ha) respectively, which is probably explained by the fact that it is less demanded by the local people as a timber tree (personal observation). Many late-successional species of the Afromontane moist forest such as $O$. welwitschii and P. adolfi-friederici are also selectively removed from the fragments, because of their usefulness for timber (Aerts et al., 2011), an additional reason for their scarcity in the forest next to coffee management.

The impact of habitat degradation through extraction of trees on species regeneration might be through seed limitation by lowering the density and fecundity of parent trees (Ghazoul, Liston \& Boyle, 1998) and by disrupting dispersal patterns of frugivores (Mendoza et al., 2009).

Considering the successful germination, survival and growth of the shade trees preferred by farmers, it is evident that the observed seedling abundance is higher than required for the replacement of old and dying shade trees. Therefore, exclosures even less in size than the present study could be effective in restoring the shade trees. It is 


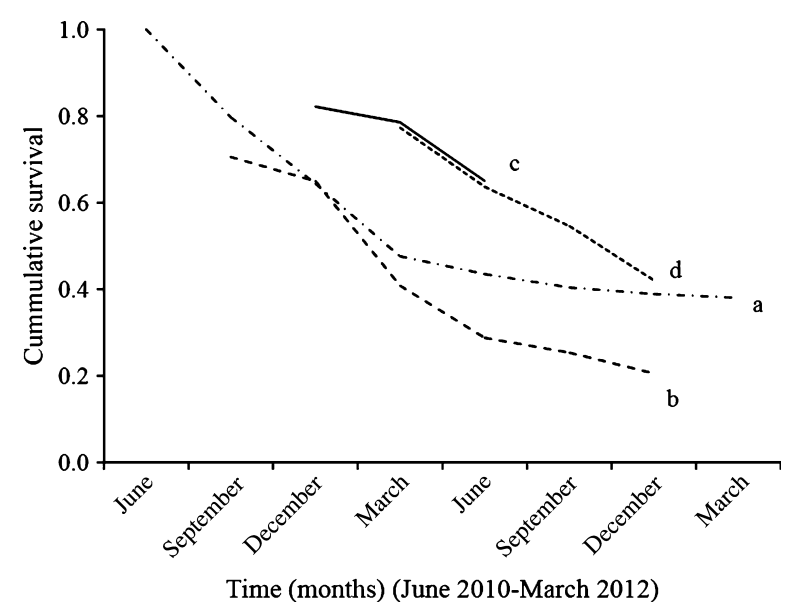

Fig 3 Seedling survival in the exclosures over time (June 2010March 2012) in Garuke coffee forest fragments, south-west Ethiopia: (a) survival of seedlings tagged at first inventory; (b) survival of new seedlings from 2nd inventory; (c) survival of new seedlings from 3rd inventory; (d) survival of new seedlings from 4 th inventory

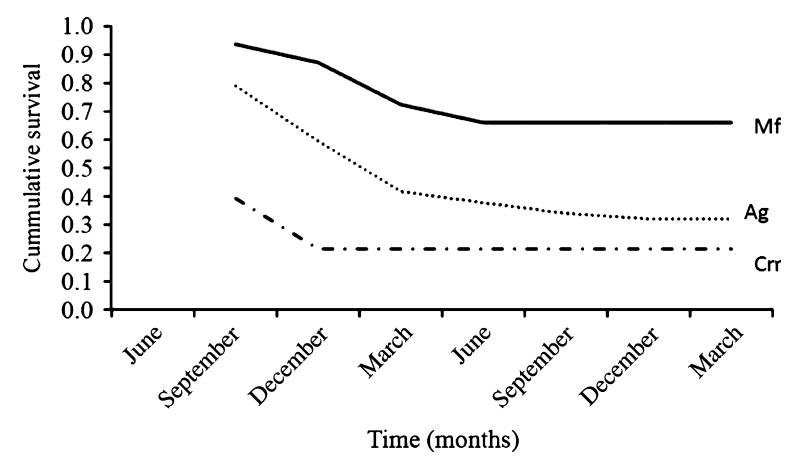

Fig 4 Comparison of survival of the three most abundant coffee shade trees in Garuke coffee forest fragments (June 2010-March 2012), south-west Ethiopia; Mf, Millettia ferruginea; Ag, Albizia gummifera/schimperiana; $\mathrm{Cm}$, Croton macrostachyus

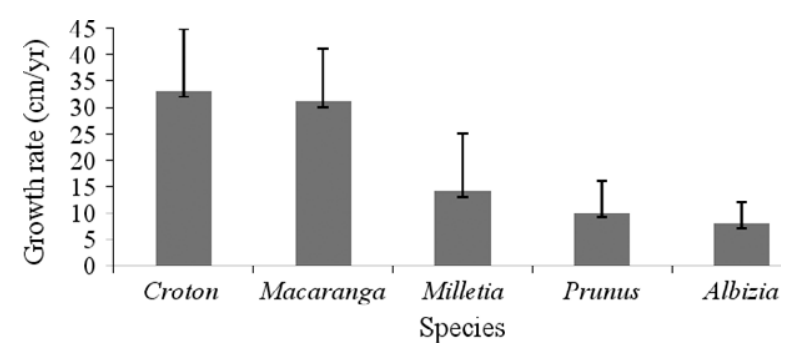

Fig 5 Comparison of relative growth of the five commonly regenerating canopy tree species in the exclosures in Garuke coffee forest fragments, south-west Ethiopia. Error bars indicate SE recommended to have them established in canopy gaps where coffee shrubs are increasingly exposed to extreme climatic conditions suboptimal for quality coffee production. The cost of constructing the exclosures can be reduced using thorny bushes and shrubs which are available at the forest margins or by reducing their size. Even in the $100 \mathrm{~m}^{2}$ the coffee yield loss caused by exclosing is low, that is about 0.021 ton clean coffee per $100 \mathrm{~m}^{2}$ (based on an estimation of 2.1 ton per ha, Aerts et al., 2011). For the restoration of the shade trees, the size of the exclosure can even be reduced as their abundance per exclosure was more than needed for the selection of suitable healthy seedlings. After 2 years of closing, healthy seedlings can be selected and protected individually from competition with shrubs and other seedlings on their way to the upper canopy. Exclosures also have to be modified in such a way that small wild animals cannot penetrate through, as they may have an impact on the survival and growth of the seedlings. Some additional study is required to optimize the number of saplings to be selected and tended per hectare.

The small exclosures were not successful to regenerate the late-successional tree species, at least not in the experimental time span of 2 years, although this was thought as a critical step to preserve the biodiversity, vitality and ecosystem services of the Ethiopian coffee forests (Aerts et al., 2011). This is mainly a consequence of seed limitation after their elimination from the upper canopy by the coffee management and extraction of the trees for their timber. The successful restoration of the climax tree species of the moist Afromontane forests in the degraded coffee forest fragments may be achieved through sowing or enrichment planting and subsequent protection of their saplings. This can be achieved if extension workers can convince local people of the additional benefits of restoration of these species (e.g. increased pollinator abundance, improved beekeeping, timber extraction and firewood production) (Benayas et al., 2009).

\section{Implications for management}

1 Small exclosures are effective means for the restoration of degraded coffee forest fragments to replace old and dying coffee shade trees.

2 Two years after closing, sufficient healthy saplings of shade tree species are present to select a few, which can be further tended by removing excess seedlings, competing 
herbs and shrubs to encourage their successful in-growth in the upper canopy.

3 Restoration of the late-successional climax tree species would require enrichment planting or sowing seeds in the exclosures.

\section{Acknowledgements}

We would like to thank all the farmers who allowed us to establish exclosures in their coffee farms. We also greatly acknowledge the anonymous reviewers who contributed more for the improvement of the manuscript. The work was financially supported by VLIR-IUC through its collaboration with Jimma University.

\section{References}

Aerts, R., Nyssen, J. \& Haile, M. (2009) On the difference between "exclosures" and "enclosures" in ecology and the environment. J. Arid Environ. 73, 762-763.

Aerts, R., Negussie, A., Maes, W., November, E., Hermy, M. \& Muys, B. (2007) Restoration of dry Afromontane forest using pioneer shrubs as nurse-plants for Olea europaea ssp. cuspidata. Restor. Ecol. 15, 129-138.

Aerts, R., November, E., Maes, W., Van der Borght, I., Negussie, A., Aynekulu, E., Hermy, M. \& Muys, B. (2008) In situ persistence of African wild olive and forest restoration in degraded semiarid savanna. J. Arid Environ. 72, 1131-1136.

Aerts, R., Hundera, K., Berecha, G., Gijbels, P., Baeten, M., Van Mechelen, M., Hermy, M., Muys, B. \& Honnay, O. (2011) Semiforest coffee cultivation and the conservation of Ethiopian Afromontane rainforest fragments. For. Ecol. Manage. 261, 1034-1041.

Altman, D.G. \& Bland, J.M. (1998) Statistics notes-time to event (survival) data. BMJ 317, 468-469.

Anthony, F., Combes, M.C., Astorga, C., Bertrand, B., Graziosi, G. \& LASHERMES, P. (2002) The origin of cultivated Coffea arabica L. varieties revealed by AFLP and SSR markers. Theor. Appl. Genet. 104, 894-900.

AsRes, T. (1996). Agroecological zones of Southwest Ethiopia. Materialien zur Ostafrikaforschung, Heft 13. Geogaphische Gesellschaft Trier, Germany, pp. 241.

Beer, J., Muschler, R., Kass, D. \& Somarriba, E. (1998) Shade management in coffee and cacao plantations. Agrofor. Syst. 38, 139-164.

Benayas, J.M.R., Newton, A.C., Diaz, A. \& Bullock, J.M. (2009) Enhancement of Biodiversity and Ecosystem Services by Ecological Restoration: a Meta-Analysis. Science 325(5944), 1121-1124.

Bote, A.D. \& Struik, P.C. (2011) Effects of shade on growth, production and quality of coffee (Coffea arabica) in Ethiopia. J. Hortic. For. 3, 336-341.
Cheng, J., Wu, G.L., Zhao, L.P., Li, Y., Li, W. \& Cheng, J.M. (2011) Cumulative effects of 20-year exclusion of livestock grazing on above- and belowground biomass of typical steppe communities in arid areas of the Loess Plateau, China. Plant Soil Environ. 57, 40-44.

Clark, J.S., Macklin, E. \& Wood, L. (1998) Stages and Spatial Scales of Recruitment Limitation in Southern Appalachian Forests. Ecol. Monogr. 68, 213-235.

Comita, L., Aguilar, S., Pérez, R., Lao, S. \& Hubbell, S. (2007) Patterns of woody plant species abundance and diversity in the seedling layer of a tropical forest. J. Veg. Sci. 18, 163-174.

Dereje, A., Oba, G., WeladjI, R.B. \& Colman, J.E. (2002) An assessment of restoration of biodiversity in degraded high mountain grazing lands in northern Ethiopia. Land Degrad. Dev. 14, 25-38.

FRANCK, N. \& VAAST, P. (2009) Limitation of coffee leaf photosynthesis by stomatal conductance and light availability under different shade levels. Trees 23, 761-769.

Geromel, C., Ferreira, L.P., Davrieux, F., Ribeyre, B.G.F., Scholz, M.B.S., Pereira, L.F.P., VAast, P., Pot, D., Leroy, T., Filho, A.A., Vieira, L.G.E., Mazzafera, P. \& Marraccini, P. (2008) Effects of shade on the development and sugar metabolism of coffee (Coffea arabica L.) fruits. Plant Physiol. Biochem. 46, 569-579. GHAzoul, J., LISTon, K.A. \& BoyLE, T.J.B. (1998) Disturbance induced density-dependent seed set in Shorea siamensis (Dipterocarpaceae), a tropical tree forest. J. Ecol. 86, 462-473. Gole, T.W. (2003). Vegetation of the Yayu Forest in SW Ethiopia: Impacts of Human Use and Implications for In Situ Conservation of Wild Coffea arabica L. Populations. Ecology and Development Series No. 10. Centre for Development Research, University of Bonn, Cuvillier Verlag, Göttingen. 171.

Harmer, R., Boswell, R. \& Robertson, M. (2005) Survival and growth of tree seedlings in relation to changes in the ground flora during natural regeneration of an oak shelterwood. Forestry 78, 21-32.

Hundera, K., Aerts, R., Fontaine, A., Van Mechelen, M., Gijbels, P., Honnay, O. \& Muys, B. (2013) Effects of Coffee Management Intensity on Composition, Structure and Regeneration of Ethiopian Montane Rainforests. Environ. Manag. 51, 801-809.

Lawes, M.J. \& Chapman, C.A. (2006) Does the herb Acanthus pubescens and/or elephants suppress tree regeneration in disturbed Afrotropical forest? For. Ecol. Manage. 221, 278-284.

Mekuria, W. \& Aynekulu, E. (2011) Exclosure land management for restoration of the soils in Degraded communal grazing lands in northern Ethiopia. Land Degrad. Dev. 24, 528-538.

MeKuRIA, W. \& VeLDKAmP, E. (2012) Restoration of native vegetation following exclosure establishment on communal grazing lands in Tigray, Ethiopia. Appl. Veg. Sci. 15, 71-83.

Mendoza, I., Gómez-Aparicio, L., Zamora, R. \& Matías, L. (2009) Recruitment limitation of forest communities in a degraded Mediterranean landscape. J. Veg. Sci. 20, 367-376.

Mengistu, T. (2001). The Role of Enclosures in the Restoration of Woody Species in Degraded Hillsides of Biyo and Tiya, Central and Northern Ethiopia. MSc thesis, Swedish University of Agricultural Sciences, Skinnskatteberg, Sweden. 
Mengistu, T., Teketay, D., Hulten, H. \& Yemshaw, Y. (2005) The role of enclosures in the recovery of woody vegetation in degraded dryland hillsides of central and northern Ethiopia. J. Arid Environ. 60, 259-281.

Morais, H., Caramori, P.H., Ribeiro, A.M.A., Gomes, J.C. \& Koguishi, M.S. (2006) Microclimatic characterization and productivity of coffee plants grown under shade of pigeon pea in Southern Brazil. Pesq. Agropec. Bras. 41, 763-770.

Muleta, D., Assefa, F., Nemomissa, S. \& Granhall, U. (2011) Socioeconomic Benefits Of Shade Trees In Coffee Production Systems In Bonga And Yayuhurumu Districts, Southwestern Ethiopia: farmers' Perceptions. Ethiop. J. Educ. Sci. 7, 39-56. MuschleR, R.G. (2001) Shade improves coffee quality in a sub-optimal coffee zone in Costa Rica. Agrofor. Syst. 85, 131-139.

Opperman, J.J. \& Merenlender, A.M. (2000) Deer herbivory as an ecological constraint to restoration of degraded riparian corridors. Restor. Ecol. 8, 41-47.
Quinn, G.P. \& Keough, M.J. (2002) Experimental Design and Data Analysis for Biologists. Cambridge University Press, Cambridge, 537.

RoBinson, G.R. \& HANDEL, S.N. (2000) Directing spatial patterns of recruitment in an urban woodland restoration. Ecol. Appl. 10, 174-188.

Schmitt, C.B., Senbeta, F., Denich, M., Preisinger, H. \& Boehmer, H.J. (2009) Wild coffee management and plant diversity in the montane rainforest of southwestern Ethiopia. Afr. J. Ecol. 48, 78-86.

SenbetA, F. \& Denich, M. (2006) Effects of wild coffee management on species diversity in the Afromontane rainforests of Ethiopia. For. Ecol. Manage. 232, 68-74.

Wassie, A., Sterck, F.J., Teketay, D. \& Bongers, F. (2009) Tree Regeneration in Church Forests of Ethiopia: effects of Microsites and Management. Biotropica 41, 110-119.

(Manuscript accepted 20 November 2014)

doi: 10.1111/aje.12203 